\title{
KARAKTERISTIK KERUPUK IKAN DENGAN SUBSTITUSI TEPUNG TULANG IKAN GABUS (Channa striata) SEBAGAI FORTIFIKAN KALSIUM
}

\author{
Yuliani $^{\star}$, Marwati, Hendri Wardana, Aswita Emmawati, Krishna Purnawan Candra* \\ Jurusan Teknologi Hasil Pertanian, Fakultas Pertanian, Universitas Mulawarman \\ Jalan Tanah Grogot Gedung Lab Terpadu, Kampus Gunung Kelua, Samarinda 75119 \\ Telepon (0541) 732146, Faks. (0541) 732146 \\ * Korespondensi: yulianicandra482@gmail.com; candra@faperta.unmul.ac.id \\ Diterima: 10 April 2018/ Disetujui: 28 Juli 2018
}

Cara sitasi: Yuliani, Marwati, Wardana H, Emmawati A, Candra KP. 2018. Karakteristik kerupuk ikan dengan subsitusi tepung tulang ikan gabus (Channa striata) sebagai fortifikan kalsium. Jurnal Pengolahan Hasil Perikanan Indonesia. 21(2): 258-265.

\begin{abstract}
Abstrak
Kerupuk ikan gabus telah dikenal luas namun biasanya terbuat dari bagian dagingnya saja. Limbah berupa tulang ikan belum dimanfaatkan secara optimal, oleh karena itu dijadikan sebagai bahan substitusi pada pembuatan produk kerupuk. Tujuan penelitian ini adalah untuk menentukan pengaruh substitusi tepung tulang ikan gabus (TTIG) sebagai fortifikan kalsium terhadap sifat sensoris dan fisika-kimia kerupuk ikan gabus. Penelitian ini menggunakan rancangan acak lengkap dengan perlakuan substitusi tepung tulang ikan gabus dalam tepung tapioka dengan kadar $(0 ; 4 ; 8 ; 12$; dan $16 \% \mathrm{~b} / \mathrm{b})$ dan di ulang sebanyak empat kali. Parameter yang dianalisis pada penelitian ini adalah sifat sensoris dan sifat fisika-kimia. Hasil penelitian menunjukkan bahwa substitusi TTIG berpengaruh nyata $(p<0,05)$ terhadap sifat sensoris rasa, aroma, warna dan tekstur serta sifat fisika-kimia kerupuk ikan gabus. Peningkatan kadar TTIG menurunkan kadar air dan volume pengembangan kerupuk ikan gabus, tetapi meningkatkan kadar protein dan kadar kalsium $(p<0,05)$. Substitusi TTIG sampai dengan $4 \%$ menghasilkan kerupuk ikan gabus dengan volume pengembangan yang sama dengan kontrol (tanpa substitusi TTIG) dengan kadar kalsium $200 \mathrm{mg} / 100 \mathrm{~g}$ dan kadar protein $14,27 \%$. Rasa dan warna kerupuk ikan gabus disukai hingga substitusi TTIG $12 \%$, sedangkan aroma dan tekstur disukai hingga substitusi TTIG $8 \%$.
\end{abstract}

Kata kunci: Channa striata, kalsium, kerupuk tulang, ikan gabus, volume pengembangan

\section{Properties of Fish Cracker with Snakehead Fish (Channa striata) Bone Flour Substitution as Calcium Fortificant}

\begin{abstract}
Snakehead fish cracker is widely known in Indonesia, but they are usually made from meat only. Fish bone waste has not been used optimally, therefore it was used as a substitute for making crackers. This experiment aimed to determine the effect of snakehead fish bone flour (SFBF) substitution as calcium fortificant on sensory and physicochemical characteristics of snakehead fish cracker (SFC). This experiment used Complete Randomized Design with four replications for each treatment. Some parameters (physicochemical properties for development volume, the contents of water, protein, and calcium as well as sensory properties were determined. The results showed that SFBF content significantly affected $(\mathrm{p}<0.05)$ the sensory characteristics of SFC for taste, aroma, colour, and texture, as well as physicochemical characteristics of SFC. Increasing of SFBF content reduced water content and development volume of SFC, although increased protein and calcium content $(\mathrm{p}<0.05)$. Substitution of SFBF up to $4 \%$ produced SFC, which showed the same development volume with control (no SFBF added). Calcium and protein contents of the SFC were $200 \mathrm{mg} / 100 \mathrm{~g}$ and $14.27 \%$, respectively. Panellists like the colour and taste of SFC produced by substitution of SFBF up to $12 \%$, while only substitution of SFBF up to $8 \%$ for aroma and texture.
\end{abstract}

Keywords: calcium, Channa striata, cracker, development volume, snakehead fish bone 


\section{PENDAHULUAN}

Kerupuk dari berbagai daerah di Indonesia biasanya mempunyai ciri khas yang karakteristiknya ditentukan dari penggunaan bahan utama berupa ikan dan udang sehingga memberikan rasa dan aroma khas. Kerupuk ikan adalah produk makanan kering yang dibuat dari tepung pati dan daging ikan dengan penambahan bahan-bahan lainnya dan bahan tambahan makanan yang diijinkan (BSN 1999). Kerupuk ikan gabus adalah kerupuk yang menggunakan daging ikan gabus sebagai pemberi rasa utama. Home industry kerupuk ikan gabus ini pertama kali berkembang di Kalimantan Selatan (Erlina et al. 2016; Hasiani 2016) dan saat ini telah berkembang luas di Indonesia termasuk di Kalimantan Timur tepatnya di Kecamatan Kota Bangun, Kabupaten Kutai Kartanegara. Kerupuk ikan gabus perlu mendapat perhatian untuk diangkat menjadi produk unggulan karena ikan gabus dikenal mempunyai beberapa sifat fungsional, yaitu dapat mempercepat penyembuhan luka (Hartini et al. 2015; Izzaty et al. 2014; Setiawan et al. 2015; Siswanto et al. 2016), mempunyai efek antiaging (Sunarno 2015), dan menunjukkan efek perbaikan gizi yang signifikan (Widodo et al. 2015).

Pemasaran kerupuk ikan gabus menunjukkan prospek yang sangat baik (Aini et al. 2014; Erlina et al. 2016), hal ini harus diantisipasi secara dini karena home industry kerupuk ikan gabus menghasilkan limbah tulang ikan yang cukup besar, mencapai 15$20 \%$ dari berat tubuhnya (Suwandi et al. 2014). Inovasi pemanfaatan tulang ikan gabus dari limbah home industry kerupuk ikan gabus perlu dilakukan, misalnya diolah menjadi tepung tulang ikan sebagai bahan tambahan pangan kaya kalsium. Kadar kalsium tepung tulang ikan bervariasi tergantung jenis ikan dan metode prosesnya. Kandungan kalsium tulang ikan gabus berkisar 16,86-22,77\% (Cucikodana et al. 2012).

Tepung tulang ikan atau bahan berkalsium telah dicobakan dalam beberapa produk olahan pangan, yaitu kerupuk ikan bandeng dengan tambahan tepung tulang ikan belida (Kusumaningrum dan Asikin 2016), biskuit dengan tambahan tepung cangkang telur (Rahmawati dan Nisa 2015) dan tepung tulang ikan madidihang (Maulida 2005), serta donat dengan penambahan tepung tulang tuna (Wardani et al. 2012), akan tetapi penambahan tepung tulang ikan dalam suatu produk mempunyai batasan karena dapat menurunkan kualitas sifat fisika-kimia dan respon sifat sensorisnya. Deborah et al. (2016) menyatakan bahwa tekstur dan rasa kerupuk aci tanpa penambahan sumber protein disukai hanya hingga penambahan tepung tulang sebesar $10 \%$.

Penelitian ini bertujuan untuk menentukan pengaruh fortifikasi tepung tulang ikan gabus sebagai pemanfaatan limbah tulang ikan dari home industry kerupuk terhadap sifat fisiko-kimia dan sensoris kerupuk ikan gabus (kerupuk dengan penambahan daging ikan gabus).

\section{BAHAN DAN METODE Bahan dan Alat}

Tepung tapioka, ikan gabus, minyak goreng dan bumbu-bumbu (garam, gula, bawang putih, ketumbar) diperoleh dari pasar tradisional di kota Samarinda. Tulang ikan gabus diperoleh dari sentra pengrajin kerupuk ikan gabus di Kecamatan Kota Bangun, Kabupaten Kutai Kartanegara. Asam klorida, asam sulfat, natrium hidroksida, katalis (Kjeldahl tablet for Wieninger method) dan phenolphtalein bahan kimia diperoleh dari Merck.

Alat yang digunakan yaitu panci kukusan, saringan, kompor, dan pisau. Pengeringan tepung tulang dan uji kadar air dilakukan menggunakan oven (Sanyo model MOV-212F, Japan) dan timbangan analitik (Mettler Toledo AL 204, Switzerland), pengukuran kadar kalsium menggunakan Spektrofotometer Serapan Atom (Shimadzu AA 6200, Japan), pengukuran protein menggunakan peralatan Kjeldahl.

\section{Metode Penelitian \\ Penyiapan daging ikan gabus}

Daging ikan gabus dipersiapkan dengan cara seperti yang dilakukan oleh UKM kerupuk ikan gabus di Kecamatan Kota Bangun, Kabupaten Kutai Kartanegara. Ikan gabus dibersihkan dari sisiknya, kepala dan 
badan ikan dipisahkan, serta kotorannya dibuang, selanjutnya daging ikan dipisahkan dari kulit dan tulang. Daging ikan gabus dihaluskan dengan blender.

\section{Penyiapan tepung tulang ikan gabus}

Penyiapan tepung tulang ikan gabus dilakukan sesuai metode yang mengacu pada Cucikodana et al. (2012) dengan modifikasi. Tulang ikan gabus bersih direbus selama 30 menit pada suhu $80^{\circ} \mathrm{C}$. Tulang ikan kemudian dibersihkan dari sisa-sisa daging yang masih menempel, selanjutnya dilakukan sterilisasi pada suhu $121^{\circ} \mathrm{C}$ selama 15 menit, setelah dingin tulang dipotong-potong 5-10 cm dan direbus kembali dalam air mendidih selama 15 menit, kemudian dicuci, ditiriskan dan dikeringkan dengan oven pada suhu $60^{\circ} \mathrm{C}$ selama 5 jam. Tulang ikan yang telah kering dihaluskan menggunakan blender dan diayak menggunakan ayakan ukuran 80 mesh.

\section{Pengolahan kerupuk}

Pengolahan kerupuk ikan gabus didasarkan pada metode yang digunakan oleh UKM kerupuk ikan gabus di Kecamatan Kota Bangun, Kabupaten Kutai Kartanegara, hanya tepung tapioka disubstitusi dengan tepung tulang ikan gabus sampai dengan $16 \%$. Perlakuan dibuat dari adonan dengan komposisi $50 \mathrm{~g}$ daging ikan gabus, $50 \mathrm{~g}$ tepung tapioka dengan substitusi tepung tulang ikan gabus 0 (kontrol), 4; 8; 12 dan 16\%, $1 \mathrm{~g}$ garam, $2 \mathrm{~g}$ gula dan $5 \mathrm{~g}$ bawang putih. Bahan dicampur sesuai dengan perlakuan dan diolah sehingga menghasilkan adonan yang rata. Adonan dibentuk menjadi bentuk silinder dengan cara dimasukkan dalam plastik polypropylen dengan panjang $15 \mathrm{~cm}$ dan diameter $3 \mathrm{~cm}$. Adonan dikukus selama 45 menit sampai adonan matang yang ditandai dengan warnanya yang menjadi bening, selanjutnya adonan diangin-anginkan selama 24 jam, Adonan didinginkan, diiris dengan ketebalan 1-2 mm, kemudian dikeringkan menggunakan oven pada suhu $85^{\circ} \mathrm{C}$ selama 5 jam. Kerupuk kering selanjutnya digoreng dalam minyak panas pada suhu $180^{\circ} \mathrm{C}$ sampai kerupuk mengembang ( \pm 1 menit).

\section{Analisis fisika-kimia}

Kadar air dianalisis dengan cara pemanasan menggunakan oven udara, dilakukan dengan cara mengeluarkan air dari bahan dengan bantuan panas pada tekanan udara $(760 \mathrm{mmHg})$. Kadar kalsium dianalisis menggunakan metode spektroskopi serapan atom $(\lambda 422,7 \mathrm{~nm})$ berdasarkan SNI 06-6989.56-2005 (BSN 2005). Kadar protein dianalisis menggunakan metode Kjeldahl, dengan cara menentukan kadar $\mathrm{N}$ total kemudian dikonversi menjadi kadar protein mengacu pada Sudarmadji et al. (2010). Volume pengembangan kerupuk diukur dengan metode yang mengacu pada Wardani et al. (2012).

\section{Evaluasi karakteristik sensoris}

Karakteristik sensoris untuk atribut warna, aroma, rasa, dan tekstur dievaluasi menggunakan uji afektif (uji hedonik) yang dilanjutkan dengan uji deskriptif (uji mutu hedonik) (Soekarto 1985). Kerupuk mentah digoreng dalam minyak panas dengan suhu $180^{\circ} \mathrm{C}$ selama 1 menit, kemudian diuji oleh panelis yang terdiri atas 20 orang yang diseleksi dari Jurusan Teknologi Hasil Pertanian Universitas Mulawarman. Panelis merupakan panelis semi terlatih. Penilaian sensoris yang digunakan adalah dengan skala 1-5.

\section{Analisis Data}

Penelitian menggunakan rancangan acak lengkap, masing-masing perlakuan diulang empat kali. Data karakteristik fisika-kimia yang diperoleh dianalisis menggunakan analisis ragam, dan dilanjutkan dengan uji Tukey pada taraf a 5\% untuk perlakuan yang menunjukkan pengaruh nyata, sedangkan data karakteristik sensoris dikonversi terlebih dahulu menjadi data interval dengan Method of Successive Interval sebelum dilakukan analisis ragam.

\section{HASIL DAN PEMBAHASAN Karakteristik Sensoris Kerupuk Ikan Gabus}

Kadar tepung tulang ikan gabus $0-16 \%$ dalam tepung tapioka yang digunakan pada pengolahan kerupuk ikan gabus memberikan 
pengaruh nyata $(p<0,05)$ terhadap sifat hedonik dan mutu hedonik untuk warna, aroma, rasa dan tekstur kerupuk ikan gabus yang dihasilkan (Tabel 1). Karakteristik sifat sensoris hedonik 1-5= sangat tidak sukasangat suka, sedangkan pada mutu hedonik untuk rasa $1-5=$ sangat tidak gurih-sangat gurih, aroma 1-5= beraroma tepung, tidak beraroma ikan, agak beraroma ikan, beraroma ikan, sangat beraroma ikan. warna 1-5= kuning kecoklatan, sangat kuning, kuning, agak kuning, putih, tekstur 1-5= sangat tidak renyah - sangat renyah.

\section{Warna}

Kadar tepung tulang ikan gabus hingga $12 \%$ dalam tepung tapioka memberikan warna yang disukai sama dengan perlakuan kontrol, sedangkan untuk perlakuan dengan kadar 16\% hanya mendapat respon agak disukai. Panelis menilai warna kerupuk kontrol dan kerupuk dengan penambahan tepung tulang ikan gabus sampai $8 \%$ mempunyai warna agak kuning, sedangkan kerupuk dengan kadar tepung tulang ikan gabus $12-16 \%$ berwarna kuning. Peningkatan substitusi tepung tulang ikan gabus memberikan kenaikan kadar kalsium dan protein kerupuk yang memberikan efek pada menurunnya kecerahan warna kerupuk. Evawati (2010) melaporkan bahwa penambahan tepung sumber kalsium seperti tepung kerang memberikan warna gelap pada produk kerupuk. Huda et al. (2001) menyatakan bahwa kenaikan kadar protein dan abu cenderung menurunkan kecerahan warna kerupuk.

Tabel 1 Karakteristik sensori kerupuk ikan gabus

(Table 1 Characteristics of snakehead fish cracker)

\section{Aroma}

Substitusi tepung tulang ikan gabus hingga $8 \%$ memberikan respon tidak berbeda dengan kontrol (tanpa substitusi), yaitu suka, tetapi substitusi yang lebih tinggi $(12-16 \%)$ cenderung menurunkan $(p<0,05)$ respon sensoris hedonik untuk aroma ini menjadi agak suka. Peningkatan kadar substitusi tulang ikan gabus diduga menjadi penyebab menurunnya kesukaan akan aroma produk kerupuk yang dihasilkan. Hal yang sama dilaporkan oleh Deborah et al. (2016) untuk kerupuk aci (tanpa penambahan daging ikan) dengan substitusi tepung tulang ikan julung-julung $0-20 \%$. Substitusi tepung tulang ikan julung-julung sampai 10\% dapat meningkatkan karakteristik sensoris hedonik untuk aroma tetapi karakteristik sensoris hedonik untuk aroma ini menurun untuk substitusi yang lebih tinggi. Hasil yang agak berbeda dilaporkan oleh Putra et al. (2015) untuk kerupuk aci (tanpa penambahan daging ikan) yang menggunakan penambahan tepung terigu. Substitusi tepung tulang ikan gabus sampai dengan 20\% memberikan pengaruh yang tidak berbeda nyata terhadap karakteristik sensoris hedonik untuk aroma.

Substitusi tepung tulang ikan gabus ini (0-16\%) cenderung menurunkan karakteristik sensoris mutu hedonik untuk aroma dari 3,46 (beraroma ikan) menjadi 2,76 (agak beraroma ikan). Substitusi tepung tulang ikan gabus sebesar $4 \%$ tidak memberikan perbedaan karakteristik sensoris mutu hedonik aroma dengan perlakuan kontrol (tanpa

\begin{tabular}{|c|c|c|c|c|c|c|}
\hline \multirow{2}{*}{\multicolumn{2}{|c|}{$\begin{array}{l}\text { Karakteristik sensori/ } \\
\text { Sensory characteristics }\end{array}$}} & \multicolumn{5}{|c|}{$\begin{array}{l}\text { Substitusi tepung tulang ikan gabus }(\% \mathrm{~b} / \mathrm{b}) \text { dalam tepung tapioka/ } \\
\text { Substitution of snakehead fish bone flour }(\% \mathrm{w} / \mathrm{w}) \text { to tapioca flour }\end{array}$} \\
\hline & & 0 & 4 & 8 & 12 & 16 \\
\hline \multirow{4}{*}{$\begin{array}{l}\text { Hedonic/ } \\
\text { Hedonic }\end{array}$} & Warna/Colour & $3.71 \pm 0.48^{\mathrm{a}}$ & $3.69 \pm 0.49^{\mathrm{a}}$ & $3.49 \pm 0.57^{\mathrm{a}}$ & $3.39 \pm 0.56^{\mathrm{ab}}$ & $3.19 \pm 0.58^{b}$ \\
\hline & Aroma/Scent & $3.80 \pm 0.72^{\mathrm{a}}$ & $3.89 \pm 0.69^{\mathrm{a}}$ & $3.75 \pm 0.67^{\mathrm{a}}$ & $3.48 \pm 0.75^{\mathrm{b}}$ & $3.46 \pm 0.71^{b}$ \\
\hline & Rasa/Taste & $3.66 \pm 0.48^{\mathrm{a}}$ & $3.70 \pm 0.46^{\mathrm{a}}$ & $3.59 \pm 0.52^{\mathrm{a}}$ & $3.53 \pm 0.50^{\mathrm{a}}$ & $3.21 \pm 0.50^{\mathrm{b}}$ \\
\hline & Tekstur/Texture & $3.71 \pm 0.56^{\mathrm{a}}$ & $3.48 \pm 0.62^{\mathrm{ab}}$ & $3.54 \pm 0.65^{\mathrm{a}}$ & $3.24 \pm 0.77^{\mathrm{bc}}$ & $3.14 \pm 0.63^{c}$ \\
\hline \multirow{4}{*}{$\begin{array}{l}\text { Mutu hedonik / } \\
\text { Hedonic quality }\end{array}$} & Warna/Colour & $4.28 \pm 0.75^{\mathrm{a}}$ & $3.83 \pm 0.91^{b}$ & $3.65 \pm 0.70^{\mathrm{b}}$ & $3.21 \pm 0.84^{c}$ & $2.88 \pm 1.01^{c}$ \\
\hline & Aroma/Scent & $3.46 \pm 0.64^{\mathrm{a}}$ & $3.35 \pm 0.68^{\mathrm{a}}$ & $3.15 \pm 0.73^{\mathrm{b}}$ & $3.01 \pm 0.68^{\mathrm{b}}$ & $2.76 \pm 0.70 c$ \\
\hline & Rasa/Taste & $3.79 \pm 0.52^{\mathrm{a}}$ & $3.68 \pm 0.50^{\mathrm{ab}}$ & $3.43 \pm 0.59^{b c}$ & $3.18 \pm 0.57^{\mathrm{c}}$ & $2.81 \pm 0.73^{\mathrm{d}}$ \\
\hline & Tekstur/Texture & $3.90 \pm 0.61^{\mathrm{a}}$ & $3.79 \pm 0.61^{\mathrm{ab}}$ & $3.54 \pm 0.62^{\mathrm{bc}}$ & $3.30 \pm 0.66^{c}$ & $2.99 \pm 0.80^{\mathrm{d}}$ \\
\hline
\end{tabular}


substitusi), tetapi peningkatan substitusinya menyebabkan penurunan aroma ikan pada kerupuk. Substitusi tepung tulang ikan gabus hingga 16\% menghasilkan kerupuk yang agak beraroma ikan.

\section{Rasa}

Substitusi tepung tulang ikan gabus dalam tepung tapioka hingga 12\% menghasilkan kerupuk dengan rasa yang tidak berbeda nyata dengan kontrol, yaitu suka, sedangkan substitusi yang lebih besar (16\%) menurunkan respon terhadap rasa kerupuk ikan gabus menjadi agak suka. Hal ini sejalan dengan penelitian Putra et al. (2015), pembuatan kerupuk dengan penambahan 20\% tepung tulang ikan gabus tanpa penambahan daging ikan gabus menurunkan karakteristik sensoris hedonik rasa.

Substitusitepung tulang ikangabussebesar $4 \%$ memberikan respon mutu hedonik untuk rasa sama dengan perlakuan kontrol yaitu agak gurih, sedangkan substitusi yang lebih tinggi (8 dan 16\%) menghasilkan kerupuk dengan rasa tidak gurih. Hal ini mungkin terjadi karena substitusi tepung tulang ikan sebesar $8 \%$ atau lebih dapat menekan rasa gurih pada kerupuk ikan gabus seperti disampaikan oleh Deborah et al. (2016) bahwa peningkatan kadar tepung tulang ikan julung-julung dalam produk kerupuk memberikan cita rasa tulang ikan yang dominan.

\section{Tekstur}

Tekstur kerupuk dengan penambahan tepung tulang ikan gabus hingga $8 \%$ disukai panelis sama dengan perlakuan kontrol dengan tekstur renyah, sedangkan perlakuan menggunakan konsentrasi yang lebih besar (12 dan 16\%) hanya mendapat respon agak disukai, dengan tekstur agak renyah. Deborah et al. (2016) melaporkan bahwa penambahan tepung tulang ikan julungjulung berpengaruh pada tekstur kerupuk. Penambahan tepung tulang ikan sampai 10\% dapat meningkatkan akseptabilitas kerupuk, tetapi penurunan akseptabilitas terjadi bila tepung tulang yang diberikan lebih besar dari $10 \%$.

\section{Sifat Fisika-kimia Kerupuk Ikan Gabus}

Kerupuk yang dihasilkan pada semua perlakuan memenuhi persyaratan mutu berdasarkan SNI 01-2713-1999 untuk kadar air (maksimal 11\%) dan kadar protein (minimal 6\%) (BSN 1999). Kadar tepung tulang ikan gabus dalam tepung tapioka memberikan pengaruh nyata $(p<0,05)$ terhadap sifat fisikokimia kerupuk ikan gabus yang dihasilkan (Tabel 2).

\section{Kadar Air dan Volume Pengembangan Kerupuk Ikan}

Kadar air kerupuk ikan gabus tanpa penambahan tepung tulang ikan yang dihasilkan pada penelitian ini yaitu 6,50\%. Kadar air tersebut cenderung menurun seiring dengan peningkatan substitusi tepung tapioka dengan tepung tulang ikan. Substitusi sebesar $8-16 \%$ mengakibatkan penurunan kadar air yang nyata $(p<0,05)$ pada kerupuk yang dihasilkan. Hal yang berbeda dilaporkan Deborah et al. (2016) dan Putra et al. (2015) yang menyatakan bahwa penambahan tepung tulang ikan pada kerupuk menyebabkan peningkatan kadar air kerupuk.

Kerupuk ikan gabus pada penelitian ini mempunyai volume pengembangan sebesar $39,75 \%$, jauh dibawah volume kembang kerupuk aci (tanpa penambahan daging ikan) dari penelitian Putra et al. (2015) yang mencapai $97,30 \%$. Penggunaan daging ikan gabus mungkin bertanggung jawab terhadap penurunan pengembangan volume kerupuk ikan gabus sebesar 60\%. Protein lebih dapat mengikat air dibanding pati (Julianti et al. 1994; Kyaw et al. 2001a; Yu dan Tan 1990; Zulfahmi et al. 2014) sehingga air yang dapat hilang dengan tibatiba pada saat proses penggorengan (faktor penentu pengembangan kerupuk pada saat penggorengan) menjadi lebih sedikit. Hal ini menyebabkan volume pengembangan kerupuk ikan lebih kecil dibanding volume pengembangan kerupuk tapioka tanpa penambahan daging ikan.

Kadar air kerupuk mentah sangat mempengaruhi pengembangan volume 
Tabel 2 Pengaruh substitusi tepung tulang ikan gabus dalam tepung tapioka terhadap sifat fisika-kimia kerupuk ikan gabus

(Table 2 Effect of snakehead fish bone flour substitution to tapioca flour on physico chemical characteristics of snakehead fish cracker)

\begin{tabular}{lccccc}
\hline \multirow{2}{*}{$\begin{array}{c}\text { Sifat fisika-kimia/ } \\
\text { Physico-chemical characteristics }\end{array}$} & \multicolumn{5}{c}{$\begin{array}{c}\text { Substitusi tepung tulang ikan gabus (\% b/b) dalam tepung tapioka/ } \\
\text { Substitution of snakehead fish bone flour (\% w/w) to tapioca flour }\end{array}$} \\
\cline { 2 - 6 } & 0 & 4 & 8 & 12 & 16 \\
\hline Daya kembang/ Swell volume (\%) & $39.75 \pm 0.48^{\mathrm{a}}$ & $39.25 \pm 0.25^{\mathrm{a}}$ & $31.25 \pm 1.11^{\mathrm{b}}$ & $21.50 \pm 0.96^{\mathrm{c}}$ & $19.50 \pm 2.10^{\mathrm{c}}$ \\
Kadar air/Moisture content (\%) & $6.50 \pm 0.36^{\mathrm{a}}$ & $6.44 \pm 0.24^{\mathrm{a}}$ & $5.60 \pm 0.06^{\mathrm{b}}$ & $5.04 \pm 0.09^{\mathrm{b}}$ & $4.17 \pm 0.32^{\mathrm{c}}$ \\
Kadar protein /Protein content (\%) & $14.01 \pm 0.21^{\mathrm{b}}$ & $14.27 \pm 0.27^{\mathrm{b}}$ & $14.53 \pm 0.19^{\mathrm{b}}$ & $14.67 \pm 0.44^{\mathrm{b}}$ & $15.50 \pm 0.18^{\mathrm{a}}$ \\
Kadar kalsium/ & $147.00 \pm 5.13^{\mathrm{e}}$ & $200.00 \pm 0.58^{\mathrm{d}}$ & $210.33 \pm 0.88^{\mathrm{c}}$ & $225.33 \pm 0.88^{\mathrm{b}}$ & $237.67 \pm 1.20^{\mathrm{a}}$ \\
Calcium content $(\mathrm{mg} / 100 \mathrm{~g})$ & & & & & \\
\hline
\end{tabular}

kerupuk, semakin rendah kadar air kerupuk mentah akan meningkatkan volume pengembangannya. Substitusi tepung tapioka dengan tepung tulang ikan gabus menyebabkan penurunan daya kembang kerupuk ikan. Substitusi tepung tapioka dengan tepung tulang ikan $4 \%$ menghasilkan kerupuk ikan dengan volume pengembangan yang sama dengan kontrol, tetapi substitusi yang lebih besar (8-16\%) menurunkan volume pengembangannya $6-10 \%$. Tepung tulang ikan diperkirakan menggantikan sejumlah air dalam adonan kerupuk sehingga kadar airnya menjadi lebih rendah, selain itu diduga tepung tulang juga mempunyai daya ikat yang lebih kuat terhadap air, sehingga dapat mengakibatkan penurunan kadar air kerupuk mentah, tetapi penambahan tepung tulang ikan tersebut mengganggu proses penghilangan air dengan tiba-tiba ketika proses penggorengan (menurunkan volume pengembangan). Hal serupa dilaporkan oleh Deborah et al. (2016) bahwa penambahan tepung tulang ikan julung-julung sebesar $10 \%$ menyebabkan penurunan volume kembang kerupuk sebesar 20\%, sedangkan Putra et al. (2015) melaporkan bahwa penambahan tepung tulang ikan sebesar 20\% menurunkan volume pengembangan kerupuk sebesar $52 \%$.

\section{Kadar Protein dan Kalsium}

Penambahan tepung tulang ikan gabus sampai dengan $16 \%$ memberikan pengaruh nyata $(p<0,05)$ terhadap kadar protein dan kalsium kerupuk ikan. Hal yang menarik pada penelitian ini adalah penambahan tepung tulang ikan gabus sampai $12 \%$ menghasilkan kerupuk dengan kadar protein yang sama dengan kontrol. Kadar protein tepung tulang ikan gabus yang dihasilkan pada penelitian ini sebesar $23,62 \%$ tergolong tepung tulang ikan dengan kandungan protein rendah untuk pembuatan kerupuk.

Penambahan tepung tulang ikan gabus pada pengolahan kerupuk ikan meningkatkan kadar kalsium kerupuk ikan gabus secara nyata. Penambahan sebanyak $16 \%$ tepung tulang ikan gabus dapat meningkatkan kandungan kalsium kerupuk ikan gabus 62\% $(p<0,05)$, yaitu $237,67 \mathrm{mg} / 100 \mathrm{~g}$ dibanding perlakuan kontrol yang hanya menghasilkan kerupuk dengan kandungan kalsium sebesar 147 mg/100 g. Kadar kalsium pada kerupuk dari hasil penelitian ini jauh lebih rendah dibandingkan dengan kerupuk ikan bandeng dengan penambahan tulang ikan belida, yaitu 6,57\% (657 mg/100 g) (Kusumaningrum dan Asikin 2016). Hal ini memberikan gambaran bahwa kadar kalsium kerupuk ikan gabus dengan penambahan tepung tulang ikan gabus masih dapat ditingkatkan dengan cara memperbaiki proses penyiapan tepung tulang ikan. Kadar kalsium tepung tulang ikan gabus yang dihasilkan pada penelitian ini hanya $0,16 \%$. Nilai ini jauh lebih rendah dari kadar kalsium tepung tulang ikan gabus hasil penelitian Cucikodana et al. (2012) yang membuat protein terlarut disertai degradasi. Hasil menunjukkan bahwa tepung tulang ikan gabus sangat potensial untuk digunakan sebagai bahan tambahan pangan 
guna meningkatkan nilai gizi kerupuk dalam hal ini kandungan kalsium dan proteinnya. Penggunaan tepung tulang ikan 8\% tidak mengubah sifat sensoris kerupuk ikan.

\section{KESIMPULAN}

Peningkatan substitusi TTIG menyebabkan penurunan penerimaan sensoris dan sifat fisika-kimia kerupuk. Kerupuk ikan gabus dengan substitusi TTIG sampai $12 \%$ disukai panelis untuk atribut warna dan rasa, TTIG sampai $8 \%$ disukai untuk atribut aroma dan tekstur. Peningkatan substitusi TTIG menurunkan kadar air dan volume pengembangan kerupuk namun meningkatkan kadar protein dan kadar kalsium. Substitusi TTIG sampai $4 \%$ menghasilkan kerupuk ikan gabus dengan volume pengembangan yang sama dengan kontrol Substitusi TTIG 16\% menghasilkan kerupuk dengan kadar air terendah tetapi mengandung kadar kalsium dan protein tertinggi.

\section{UCAPAN TERIMAKASIH}

Penulis mengucapkan terima kasih yang sebesar-besarnya pada Fakultas Pertanian Universitas Mulawarman yang telah membiayai penelitian ini melalui Hibah Penelitian Fakultas Pertanian Universitas Mulawarman Tahun 2017.

\section{DAFTAR PUSTAKA}

Aini M, Mahyudin I, Mahreda S. 2014. Analisis usaha pengolahan kerupuk ikan gabus (Channa striata Bloch) peserta program pemberdayaan konsultan keuangan mutra bank (KKMB) di Kalimantan Selatan (Studi Pemberdayaan KKMB di Kota Banjarmasin). Fish Scientie. 4(7): 23-24.

[BSN] Badan Standardisasi Nasional. 1999. SNI 01-2713-1999. Kerupuk Ikan. Jakarta (ID): Badan Standardisasi Nasional.

[BSN] Badan Standardisasi Nasional. 2005. SNI 06-6989.56-200. Air dan air limbah - Bagian 56: Cara uji kadar kalsium (Ca) dengan Spektrofotometer Serapan Atom (SSA). Jakarta (ID): Badan Standardisasi Nasional.
Cucikodana Y, Supriadi A, Purwanto B. 2012. Pengaruh perbedaan suhu perebusan dan konsentrasi $\mathrm{NaOH}$ terhadap kualitas bubuk tulang ikan gabus (Channa striata). Jurnal Fishtech. 1(1): 91-101.

Deborah T, Afrianto E, Pratama RI. 2016. Fortifikasi tepung tulang Julung-julung sebagai sumber kalsium terhadap tingkat kesukaan kerupuk. Jurnal Perikanan Kelautan. 7(1): 48-53.

Erlina S, Ilma Ifada I, Supianor. 2016. Prospek usaha pembuatan kerupuk ikan gabus. Ziraa'ah. 41(2): 237-242.

Evawati D. 2010. Pemanfaatan kerang fortifikasi kalsium pada krupuk aneka rasa untuk peningkatan kandungan gizi dan tingkat penerimaan konsumen. Jurnal Akademi Keperawatan Pamenang. 1(2): 13-17.

Hartini PS, Dewi N, Hayatie L. 2015. Esktrak ikan haruan (Channa striata) menurunkan jumlah makrofag pada fase inflamasi proses penyembuhan luka. Jurnal Dentofasial. 14(1): 6-10.

Hasiani Y. 2016. Analisis usaha mikro, kecil dan menengah pengolahan kerupuk ikan gabus di Kabupaten Banjar. EnviroScienteae. 13(1): 91-94.

Huda N, Abdullah A, Babji AS. 2001. Substitution of tapioca flour with surimi powder in traditional crackers (Keropok Palembang). In 16th Scientific Conference Nutrition Society of Malaysia (pp. 1-6). Kuala Lumpur: Nutrition Society Malaysia.

Izzaty A, Dewi N, Indah D, Pratiwi N. 2014. Ekstrak haruan (Channa striata) secara efektif menurunkan jumlah limfosit fase inflamasi dalam penyembuhan luka. Jurnal Dentofasial. 13(3): 176-181.

Julianti J, Belo P, Smith E, McProud L. 1994. Egg white powder in extruded fish crackers. International Journal of Food Science and Technology. 29: 315-320.

Kusumaningrum I, Asikin AN. 2016. Karakteristik kerupuk ikan fortifikasi kalsium dari tulang ikan belida (Chitala sp.). Jurnal Pengolahan Hasil Perikanan Indonesia. 19(3): 233-240. 
Kyaw ZY, Yu SY, Cheow CS, Dzulkifly MH, Howell NK. 2001. Effect of fish to starch ratio on viscoelastic properties and microstructure of fish cracker ('keropok') dough. International Journal of Food and Technology. 36: 741-747.

Maulida N. 2005. Pemanfaatan tepung tulang ikan madidihang (Thunnus albacares) sebagai suplemen dalam pembuatan biskuit (Crackers). [Skripsi]. Bogor (ID): Fakultas Perikanan dan Ilmu Kelautan, Institut Pertanian Bogor.

Putra MRA, Nopianti R, Herpandi. 2015. Fortifikasi tepung tulang ikan gabus (Channa striata) pada kerupuk sebagai sumber kalsium. Jurnal Fishtech. 4(2): 128-139.

Rahmawati WA, Nisa FC. 2015. Fortifikasi kalsium cangkang telur pada pembuatan cookies (Kajian konsentrasi tepung cangkang telur dan baking powder). Jurnal Pangan dan Agroindustri. 3(3): 1050-1060.

Setiawan MR, Dewi N, Oktaviyanti IK. 2015. Ekstrak ikan haruan (Channa striata) meningkatkan jumlah neokapiler pada penyembuhan luka. Jurnal Dentofasial. 14(1): 1-5.

Siswanto A, Dewi N, Hayatie L. 2016. Effect of haruan (Channa striata) extract on fibroblast cells count in wound healing. Journal of Dentomaxillofacial Science. 1(1): 12-15.

Soekarto ST. 1985. Penilaian Organoleptik untuk Industri Pangan dan Hasil Pertanian. Jakarta: Bhratara Karya Aksara.
Sudarmadji S, Haryono B, Suhardi. 2010. Prosedur Analisis Bahan Makanan dan Pertanian. Yogyakarta (ID): Liberty.

Sunarno. 2015. Potential of glutathione antioxidant in the hippocampus repair: Preliminary study on bioactive materials antiaging of snakehead fish (Channa striata) in animal models of aging. International Journal of Science and Engineering. 8(1): 22-25.

Suwandi R, Nurjanah, Winem M. 2014. Proporsi bagian tubuh dan kadar proksimat ikan gabus pada berbagai ukuran. Jurnal Pengolahan Hasil Perikanan Indonesia. 17(1): 22-28.

Wardani DP, Liviawaty E, Junianto. 2012. Fortifikasi tepung tulang tuna sebagai sumber kalsium terhadap tingkat kesukaan donat. Jurnal Perikanan dan Kelautan. 3(4): 41-50.

Widodo S, Riyadi H, Tanziha I, Astawan M. 2015. Perbaikan status gizi anak balita dengan intervensi biskuit berbasis blondo, ikan gabus dan beras merah. Junal Gizi Pangan. 10(2): 85-92.

Yu SY, Tan LK. 1990. Acceptability of crackers ("keropok") with fish protein hydrolysate. International Journal of Food Science and Technology. 25: 204-208.

Zulfahmi AN, Swastawati F, Romadhon. 2014. Pemanfaatan daging ikan tenggiri (Scomberomorus commersoni) dengan konsentrasi yang berbeda pada pembuatan kerupuk ikan. Jurnal Pengolahan dan Bioteknologi Hasil Perikanan. 3(4): 133-139. 